\title{
The Effect of Nano Drilling Fluids on Reduction of Clay Swelling
}

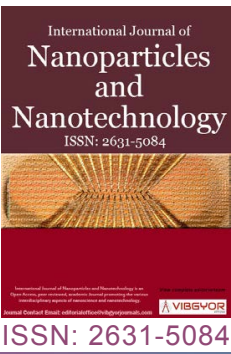

\section{Ahmad Zakaria Noah ${ }^{1 *}$, Ali Ali El-Khadragy'2, Fatma Said Ramadan ${ }^{2}$ and Mahmoud Ibrahim Mohamed ${ }^{3}$}

${ }^{1}$ Egyptian Petroleum Research Institute, Cairo, Egypt

${ }^{2}$ Faculty of Science, Geology Dept, Zagazig University, Egypt

${ }^{3}$ General Company for Researches and Ground Water, 19 Emad Eldin, Cairo, Egypt

\begin{abstract}
Shales make up about three fourths of drilled formation and over $90 \%$ of the wellbore instability problems that occur in shales. Even though shale stability has been studied for several decades, it still a serious problem in not only the petroleum industry but also in the mining and construction industries. Before any measures are taken to address this problem, it is crucial that potentially problematic formations and the mechanisms of wellbore instability be identified. Once the mechanisms are understood, well planning, drilling fluid design, and drilling operation strategies can be implemented to ensure wellbore stability. Due to the unique mechanical and physicochemical properties of shales, it is well- recognized that wellbore instability in shales is a complicated problem.

Shale cuttings consisting of different montmorillonite content were collected from four different wells in Sinai. They were evaluated using X-ray diffraction (XRD), X-ray fluorescence (XRF) and cation exchange capacity (CEC) using Methylene Blue (MB), hence classified into shale 1, 2,3 and 4. Swelling index of the shale measured using compressed disks of shale in contact with OCMA bentonite for 20 hrs using the Linear Swell Meter (LSM). Nanoparticles in terms of CuO, Graphene nanoplatelets and $\mathrm{SiO}_{2}$ used as an inhibitor of swelling of shale cuttings. The inhibitors are added to OCMA bentonite as well.
\end{abstract}

Swelling of the shale directly related to montmorillonite content, more montmorillonite means more swelling in contact with OCMA bentonite.

The inhibition of swelling of these shale cuttings using $\mathrm{KCl}$ achieved a decrease in swelling that ranged from $15 \%$ at $7 \%$ (shale 1 ), $14 \%$ at $6 \%$ (shale 2 ), $14 \%$ at $4 \%$ (shale 3 ) and $17 \%$ at $9 \%$ (shale 4 ).

\section{Introduction}

Maintaining a stable wellbore is one of the major challenges when drilling a well. Studies indicate that, unscheduled events relating to wellbore instability account for more than $10 \%$ of well costs, with estimates over $\$ 1$ billion in annual cost to the industry. Preventing shale instability is a high priority to every phase of the drilling fluids industry, from research and development efforts to field implementation by the mud engineers. New technol-

*Corresponding author: Ahmad Zakaria Noah, Egyptian Petroleum Research Institute, Cairo, Egypt Accepted: April 25, 2019; Published: April 27, 2019

Copyright: (C) 2019 Noah AZ, et al. This is an open-access article distributed under the terms of the Creative Commons Attribution License, which permits unrestricted use, distribution, and reproduction in any medium, provided the original author and source are credited.

Noah et al. Int J Nanoparticles Nanotech 2019, 5:024

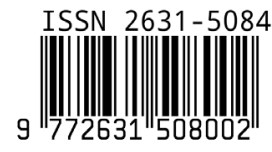


ogies are continually being developed and applied and earlier technologies refined.

Shale causes world's $70 \%$ of wellbore instability problems. Shale instability is caused due to the presence of clay minerals into the shale. These clay minerals in particular kaolinite, smectite and montrolite have great affinity with the water. However, clay minerals start to swell after they interact with the water because of the special behavior of the clays is due to their unique structures. The crystal structure of swelling clays consists of $\mathrm{Al}-\mathrm{OH}$ or $\mathrm{Fe}-\mathrm{OH}$ or $\mathrm{Mg}-\mathrm{OH}$ octahedral, sandwiched by two Si-O tetrahedral layers. These layers are always deficient in positive charges because of cation substitution. Interlayer cations are required to balance the negative layer charges. When the exchangeable cations are hydrated during water injection and water molecules enter the space between the structure layers, the distance between the two layers increases leading to clay swelling. And as a result, clay swelling raised the wellbore instability such as shale sloughing, tight hole, caving and reduce efficiency of mud to lift the drilled cuttings. Clay swelling reduces the rate of penetration (ROP) due to bit balling with sticky clay.

\section{Clay swelling}

All classes of clay minerals adsorb water, but smectites take up much larger volume than do other classes because of their expanding lattice. For this reason, most of the studies on clay swelling have been made with smectites, particularly with montmorillonite. Two swelling mechanisms are recognized:

Crystalline swelling: It's sometimes called surface hydration and it occurs in all types of clay minerals. This short-range swelling of clay minerals is known experimentally to occur in a discrete fashion, through the stepwise formation of integer layer or mixtures of integer-layer hydrates. These layer spacing transitions are thermodynamically analogous to phase transitions. Several layers of water molecules may line up to form a quasi-crystalline structure between unit layers which results in an increased interlayer spacing [1].

Osmotic swelling: Is limited to certain clay minerals, which contain exchangeable cations in the interlayer region. If the concentration of cations in the interlayer is higher than that of the surrounding water, water molecules can be drawn into the interlayer to restore cation equilibrium. This type of swelling can result in significantly larger volume increases (typically interlayer spacings of $20 \AA$ to 130 $\AA$ ) than that which results from crystalline swelling. The tendency of $\mathrm{Na}^{+}$-saturated smectites to swell in this osmotic fashion is the principal cause of shale deposit instability, which can potentially lead to the collapse of bore-holes in oil well drilling operations [2].

\section{Drilling fluid additives}

When drilling is expected to occur in watersensitive zones, the selection of the fluid becomes even more important. To maintain a stable borehole through such zones, an inhibitor drilling fluid will often be required [3].

The high sensitive water formation may call for the use of non-aqueous fluids as oil, alcohol, or foam, but for environmental reasons, the water base fluid with inhibitors preferred to use.

The use of non-inhibitive drilling fluids to drill shale formations usually results in wellbore instability problems. Therefore, various chemicals and technologies are known as "clay Inhibitors" have been employed to control clay swelling in petroleum reservoirs. The commercially available clay inhibitors used widely in the petroleum industry can be broadly classified as inorganic brines, inorganic cationic polymers and organic polymers [4].

\section{Nanofluids}

The nanofluids defined as the fluid which is used in oil and gas drilling and exploitation and contains at least one nanoscale additive. They classified as simple nano-fluids and advanced nano-fluids. Simple nanofluids contain nanoparticles of only one dimension. Advanced nanofluids are one with multiple nanosizes. These types of fluids significantly reduce the total solids content in the mud. The laws that govern the nanoparticles surface behavior or interaction with surrounding medium are different from the normal laws which govern the behavior of macro and micro-scale behavior [5].

The main application of nanoparticles would be to control the spurt and fluid loss into the formation and hence control formation damage. The nanoparticles can form a thin, non-erodible and impermeable 
mud cake. Due to its high surface to volume ratio the particles in the mud cake matrix can easily be removed by traditional cleaning systems during completion stages. Thus, the Nanoparticles can be used as rheology modifiers, fluid loss additives and shale inhibitors with unparalleled properties for very small concentrations of the particle [6]. Thus, the smart fluids based on nanofluids can be a used effectively in horizontal, directional shale drilling due to formation of a barrier between drilling mud and shale, as nanoparticles can easily penetrate into the shale and hence drastically reduce the shale-drilling mud interactions and stabilizes the wellbore [7].

The laboratory procedure involved plugging the pore throat of the shale samples with silica Nanoparticles of $20 \mathrm{~nm}$. The shale pore sizes are an average of 10 to $30 \mathrm{~nm}$. The conventional drilling fluids have much larger particle diameters in the range of 100 microns. The particle sizes should not be larger than one third of the pore throat size to form an effective bridge and also particles should be at least $5 \%$ by volume of the drilling fluid [8].

This study target to inhibit shale swelling process throughout additive potassium chloride $(\mathrm{KCl})$ and nanoparticles ( $\mathrm{CuO}$, Graphene and $\mathrm{SiO}_{2}$ ) to waterbased mud and using linear swell meter (LSM) and Shale compact disks.

\section{Methodology}

\section{Shale samples}

Shale core samples provided by The General Company for Research and Ground water were homogenized and ground to $75 \mu \mathrm{m}$.

\section{Bentonite samples}

OCMA bentonite provided by Egypt Bentonite \& Derivatives Company.

\section{Additives}

Nanoparticles: Copper oxide (CuO), Graphene nanoplatelets and Silica $\left(\mathrm{SiO}_{2}\right)$ in nanometer size prepared throughout electronic and magnetic material division in CMRDI and examined by using SEM.

Inorganic Salt: Potassium chloride salt $\mathrm{KCl}$ provided by El NASR Pharmaceutical Chemicals Company.

\section{Techniques}

\section{Characterization of shale samples}

The mineralogy and chemistry of shale samples are characterized by using X-ray Diffraction (XRD) and X-ray fluorescence (XRF).

\section{Mineralogical analysis}

Shale cores were characterized using X-ray Diffraction (XRD) for bulk minerals analysis (Philips powder type PW 1730) with Ni-filtered Fe radiation $(\lambda=1.79)$ at $30 \mathrm{kV}$ and $20 \mathrm{~mA}$. The scans were limited to the range $2 \theta=4^{\circ}$ to $60^{\circ}$.

\section{Chemical analysis}

Quantitative analysis of shale cuttings were carried out using X-ray fluorescence spectroscopy (XRF) (Philips PW 1410). Tube voltage and current for $\mathrm{W}$ target were $40 \mathrm{KV}$ and $60 \mathrm{MA}$, respectively. Loss of ignition L.O.I., that was obtained by heating sample powder to $1000^{\circ} \mathrm{C}$ for $2 \mathrm{hrs}$.

\section{Chemo-Physical analysis}

\section{Cation exchange capacity (CEC).}

This test is usually applied to determine the capacity of the clay to adsorb cations from solution. The cation exchange capacity is measured in terms of milliequivalent per 100 grams (meq/100 g). The Cation exchange capacity using methylene blue is specially designed to determine the montmorillonite ratio in clay samples.

\section{SEM of nanoparticles}

Morphology of nanoparticles was examined using SEM Model Quanta 250 FEG.

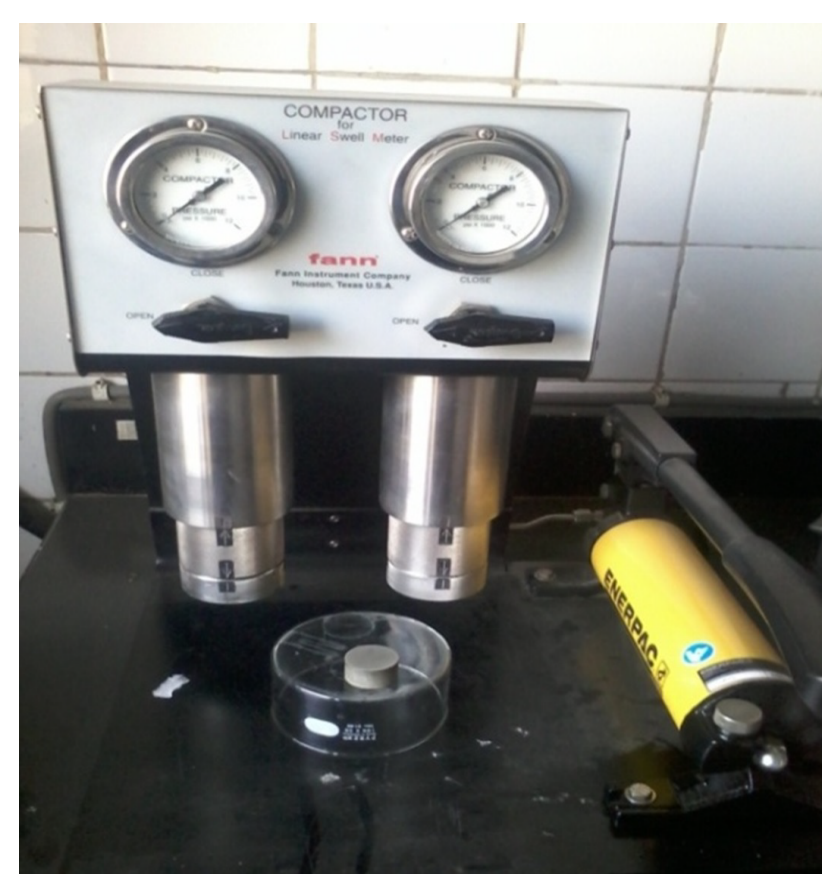

Figure 1: Compactor and shale core plug. 


\section{Preparation of shale core disk (plug)}

Shale samples homogenized and grind to $75 \mu \mathrm{m}$ (200 mesh). $20 \mathrm{~g}$ of shale cutting compacted under a constant pressure of 10,000 psi for 1.5 hrs using a compactor for the linear swell meter as shown in Figure 1.

\section{Preparation of drilling fluid}

Drilling fluid without additives: All the samples of drilling fluid are based on the formulation of 350 $\mathrm{ml}$ of fresh water with $5 \%$ bentonite then mixed using a Hamilton Beach mixer for 30 min.

\section{Drilling fluid with additives}

OCMA bentonite mixed with the different percent of nanoparticles and potassium chloride salt $(\mathrm{KCl})$ with $350 \mathrm{ml}$ of fresh water in Hamilton Beach mixer for 15-20 min as shown in Figure 2.

\section{Drilling fluid using ultrasonication}

Nanoparticles added to $350 \mathrm{ml}$ of water, then
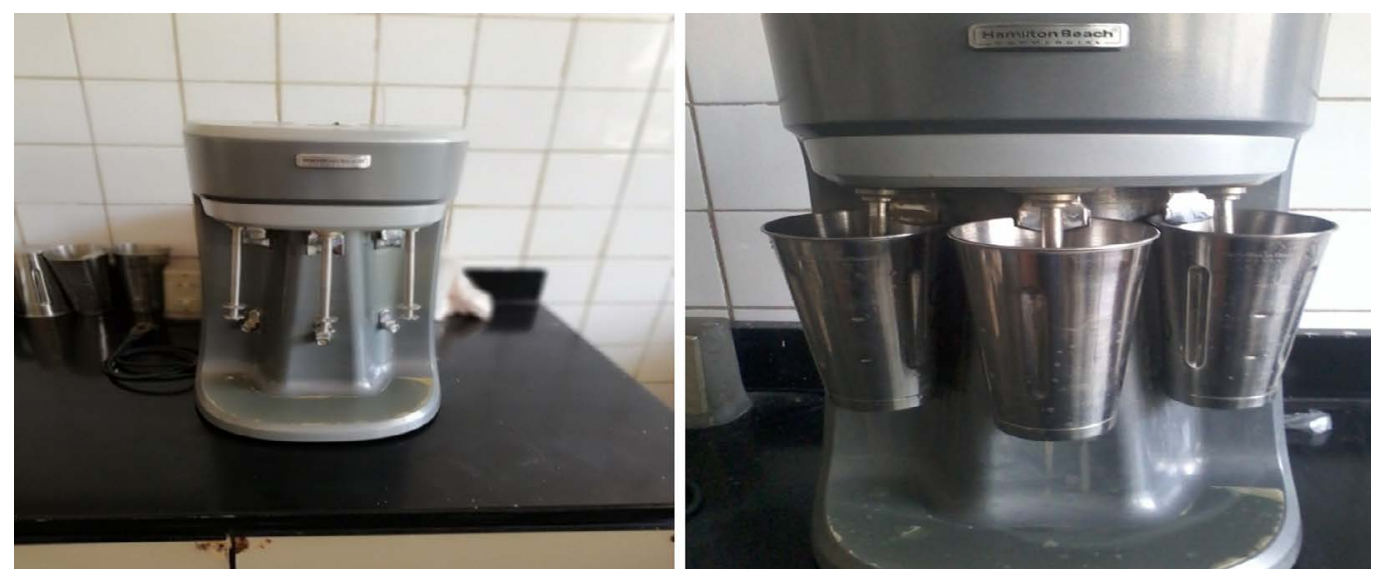

Figure 2: Hamilton beach mixer.

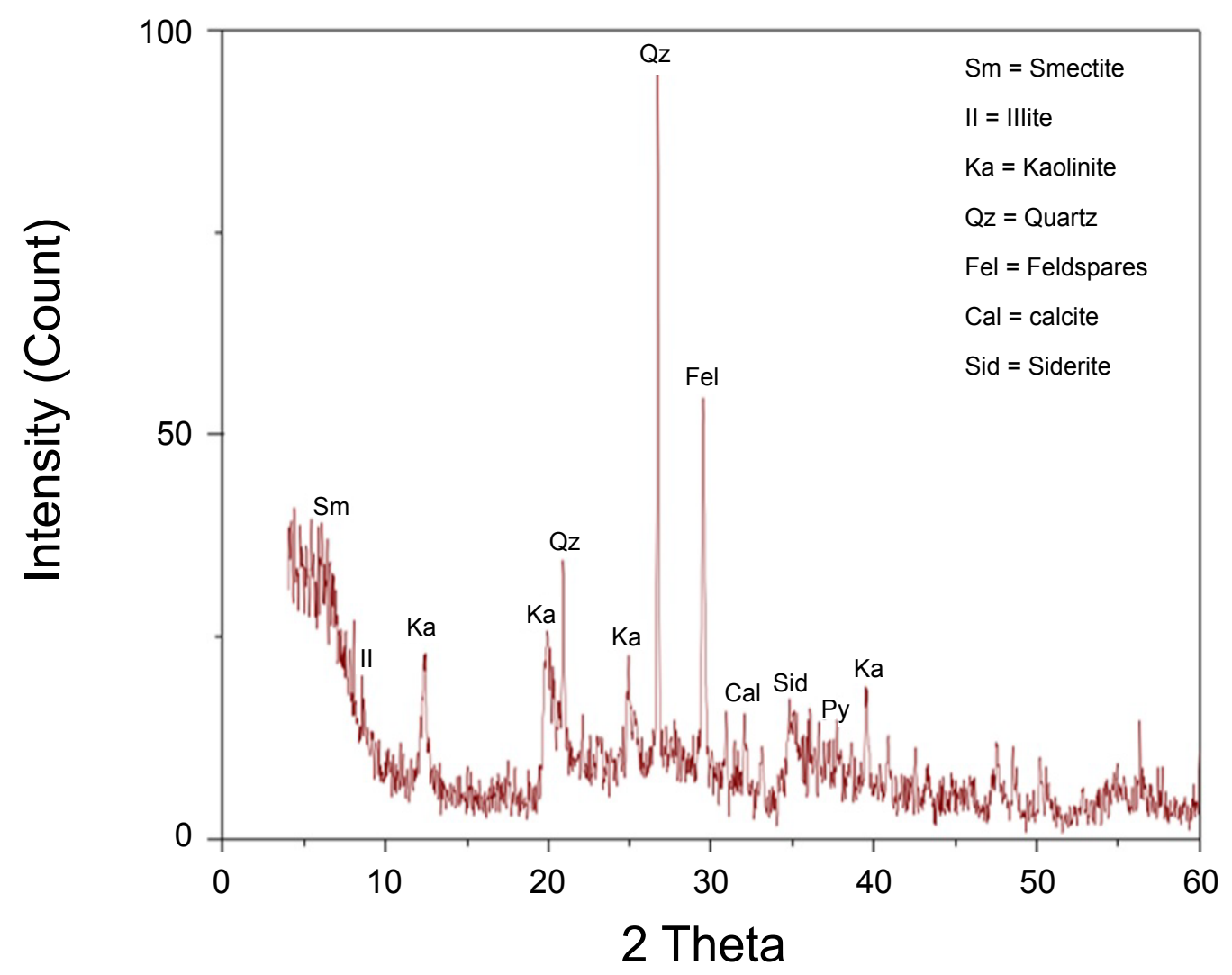

Figure 3: X-ray diffractogram of shale 1. 
using ultrasonication for $30 \mathrm{~min}$ followed by addition of (OCMA, 5\%) bentonite and mixing for $30 \mathrm{~min}$.

\section{Results and Discussion}

- Characterization of shale samples

- Mineralogical Analysis

\section{X-ray Diffraction (XRD) of shale samples}

Shale cutting was characterized using X-ray Diffraction (XRD) for bulk samples and identified non-clay minerals that including quartz, feldspars, calcite, dolomite, siderite and pyrite as shown in Figure 3, Figure 4, Figure 5 and Figure 6.

- Quartz $\left(\mathrm{SiO}_{2}\right)$ was reported in all samples and identified by the characteristic reflection peaks at 4.26, 3.34 and $1.82 \AA$.

o Feldspar minerals were reported as traces in all samples as Na-feldspar and K-feldspar. Na-feldspar identified by the characteristic reflection peak at $3.19 \AA$ and K-feldspar identified by the characteristic reflection peak at $3.25 \AA$.

- Calcite $\left(\mathrm{CaCO}_{3}\right)$ was detected in all samples. It was identified by the characteristic reflection peaks at 3.04, 2.85 and $2.09 \AA$. o Siderite $\left(\mathrm{FeCO}_{3}\right)$ was detected in all. It was identified by the characteristic reflection peak at $2.80,1.79$ and $3.59 \AA$.

- Pyrite $\left(\mathrm{FeS}_{2}\right.$ ) was detected in two samples only and it in shale (2) and shale (4). It was identified by the characteristic reflection peak at 2.70 and $2.42 \AA$.

- Dolomite $\left(\mathrm{CaMg}\left(\mathrm{CO}_{3}\right)_{2}\right)$ was reported only in shale (2). It was identified by the characteristic reflection peak at 2.89, 1.78 and $2.19 \AA$.

\section{Chemical analysis}

Table 1 shows the chemical composition of the studied samples using $x$-ray fluorescence (XRF) and all the examined samples consist mainly of $\mathrm{SiO}_{2}, \mathrm{Al}_{2} \mathrm{O}_{3}$ and $\mathrm{Fe}_{2} \mathrm{O}_{3}$ in a descending order of abundance. A minor to trace amounts of $\mathrm{CaO}, \mathrm{K}_{2} \mathrm{O}$, $\mathrm{MgO}, \mathrm{Na}_{2} \mathrm{O}, \mathrm{TiO}_{2}, \mathrm{SO}_{3}, \mathrm{MnO}$, and $\mathrm{P}_{2} \mathrm{O}_{5}$ were also detected. The percentage of the main oxides $\mathrm{SiO}_{2}$ and $\mathrm{Al}_{2} \mathrm{O}_{3}$ are considered as the main constituent of clay minerals.

Iron $\left(\mathrm{Fe}_{2} \mathrm{O}_{3}\right.$ ) Present in two phases in clay minerals as staining iron and structural iron [9]. In addition to traces of iron carbonate, siderite $\left(\mathrm{FeCO}_{3}\right)$ and iron sulfide, pyrite $\left(\mathrm{FeS}_{2}\right)$ were revealed by XRD.

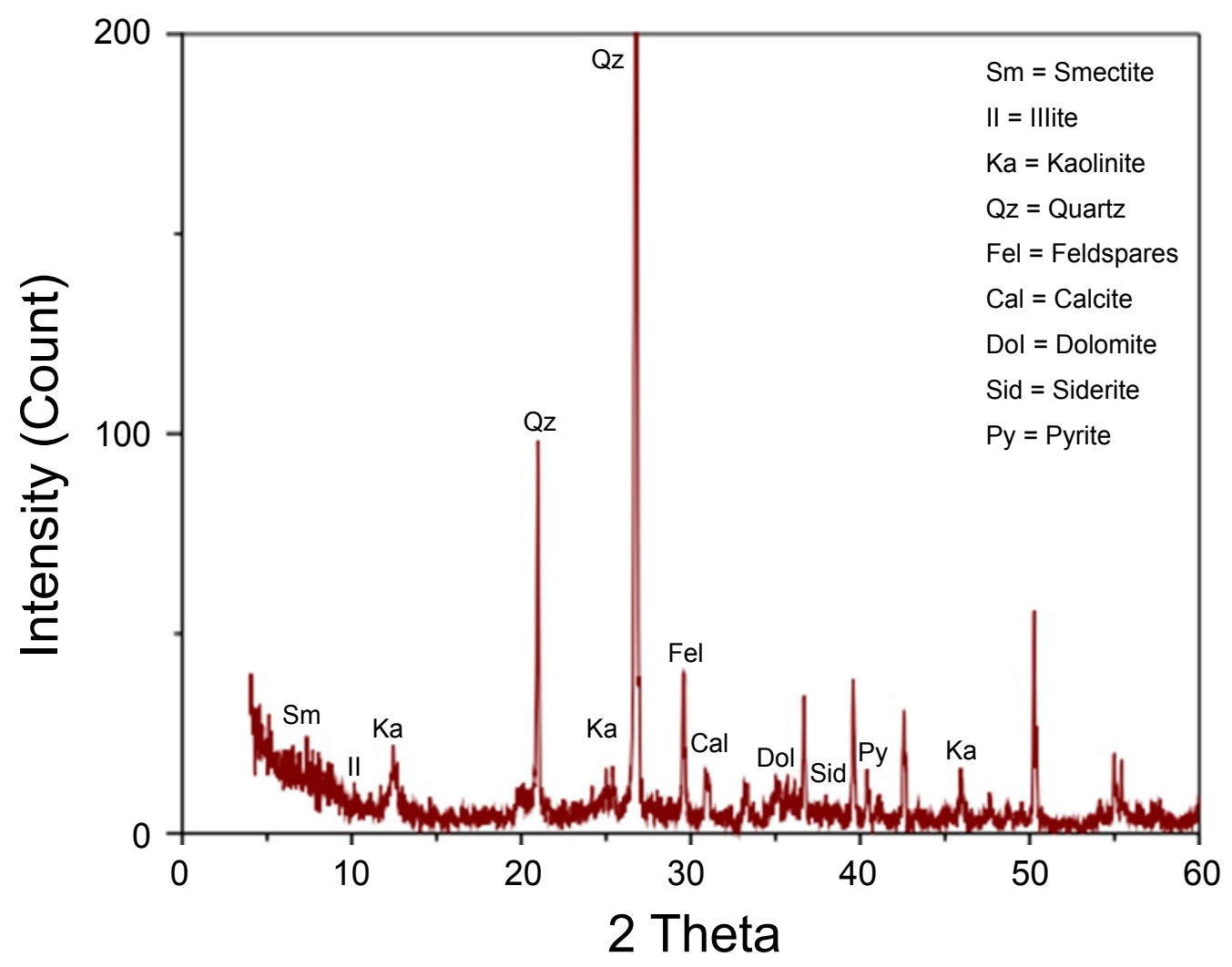

Figure 4: X-ray diffractogram of shale 2. 


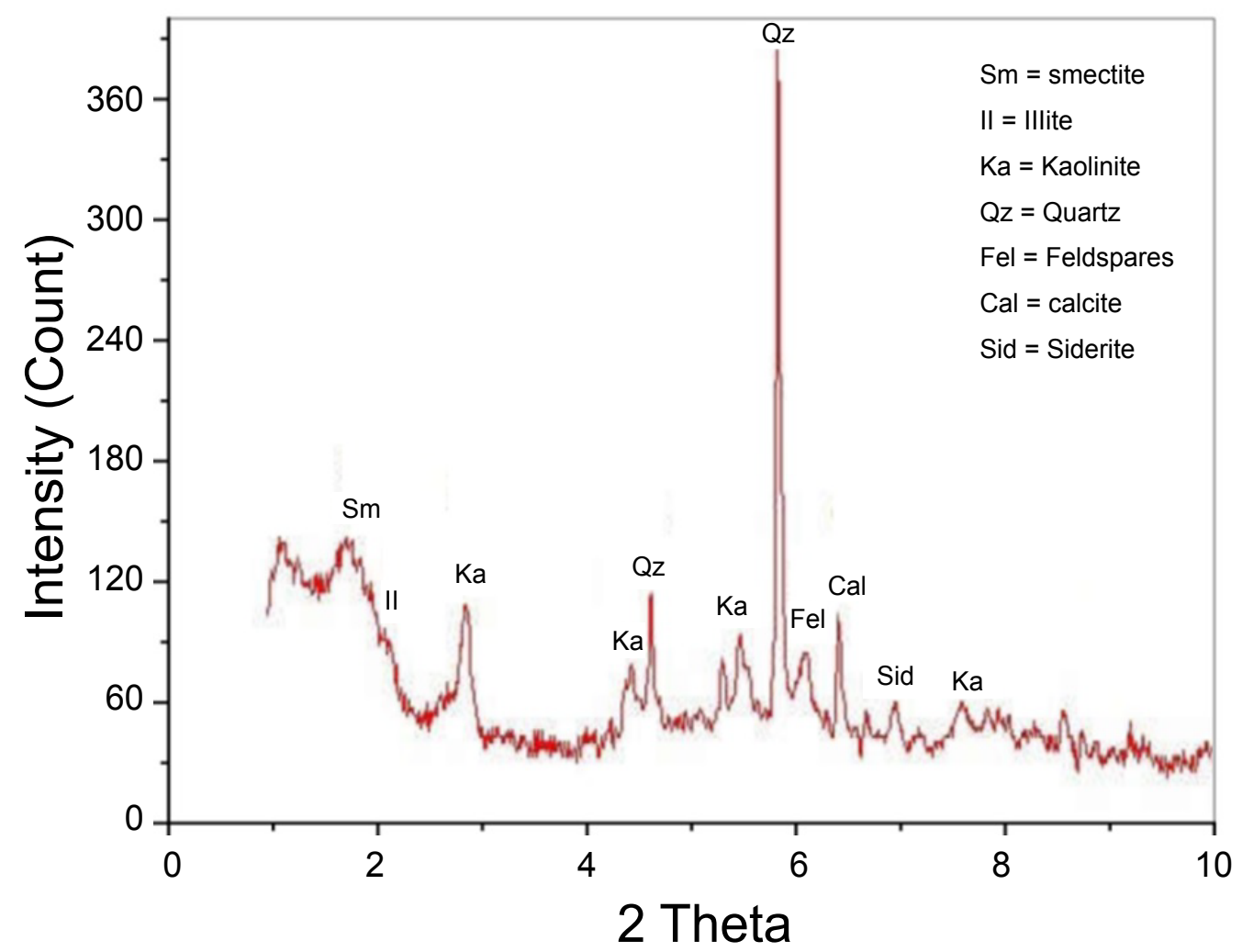

Figure 5: X-ray diffractogram of shale 3.

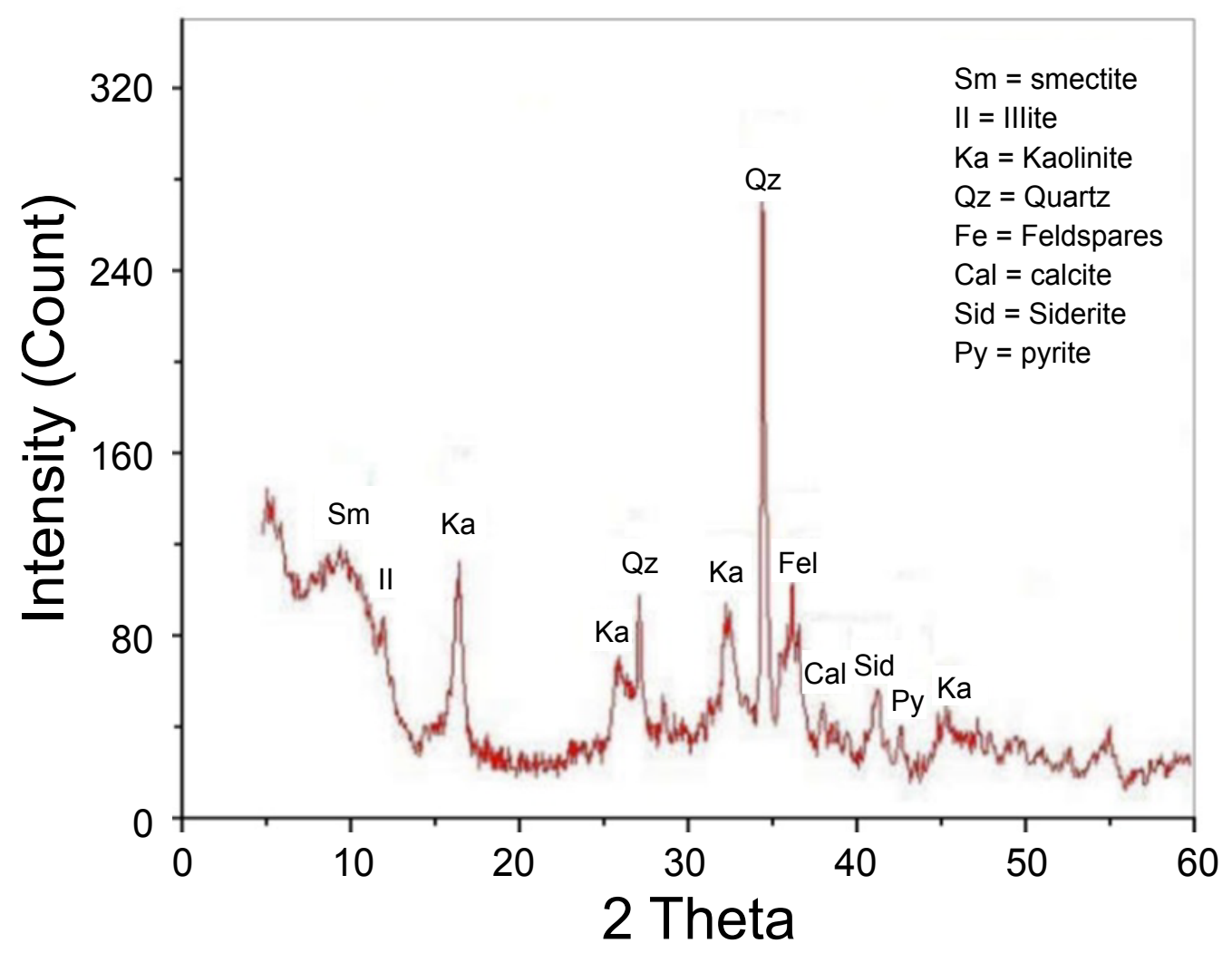

Figure 6: X-ray diffractogram of shale 4. 
Table 1: The chemical composition of shale samples.

\begin{tabular}{|l|l|l|l|l|}
\hline Oxides content & Shale (1) & Shale (2) & Shale (3) & Shale (4) \\
\hline $\mathrm{SiO}_{2}$ & 51.8 & 54.3 & 55.7 & 51.4 \\
\hline $\mathrm{Al}_{2} \mathrm{O}_{3}$ & 15.5 & 11.9 & 14.6 & 13.8 \\
\hline $\mathrm{Fe}_{2} \mathrm{O}_{3}$ & 8.33 & 7.23 & 5.02 & 10.07 \\
\hline $\mathrm{CaO}$ & 1.21 & 7.2 & 3.11 & 2.3 \\
\hline $\mathrm{Na}_{2} \mathrm{O}$ & 1.1 & 0.61 & 1.3 & 0.98 \\
\hline $\mathrm{K}_{2} \mathrm{O}$ & 2.2 & 1.14 & 3.24 & 1.25 \\
\hline $\mathrm{P}_{2} \mathrm{O}_{5}$ & 0.25 & 0.23 & 0.15 & 0.49 \\
\hline $\mathrm{MnO}^{\mathrm{NiO}}$ & 0.68 & 0.37 & 0.47 & 0.09 \\
\hline $\mathrm{TiO}_{2}$ & 1.27 & 0.81 & 0.97 & 1.22 \\
\hline $\mathrm{SO}_{3}$ & 0.71 & 0.63 & 0.52 & 0.65 \\
\hline $\mathrm{MgO}$ & 1.43 & 1.18 & 2.44 & 1.82 \\
\hline L.O.I & 15.55 & 14.1 & 12.23 & 15.96 \\
\hline
\end{tabular}

All the examined samples consist mainly of $\mathrm{SiO}_{2}$, $\mathrm{Al}_{2} \mathrm{O}_{3}$ and $\mathrm{Fe}_{2} \mathrm{O}_{3}$ in a descending order of abundance. A minor to trace amounts of $\mathrm{CaO}, \mathrm{K}_{2} \mathrm{O}, \mathrm{MgO}, \mathrm{Na}_{2} \mathrm{O}$, $\mathrm{TiO}_{2}, \mathrm{SO}_{3}, \mathrm{MnO}$, and $\mathrm{P}_{2} \mathrm{O}_{5}$ were also detected. The percentage of the main oxides $\mathrm{SiO}_{2}$ and $\mathrm{Al}_{2} \mathrm{O}_{3}$ are considered as the main constituent of clay minerals.

$\mathrm{CaO}$ and $\mathrm{Na}_{2} \mathrm{O}$ are partly located in the interlayer position (gallery) of smectite [10]. In addition to $\mathrm{CaO}$ content referred to the presence of calcite $\left(\mathrm{CaCO}_{3}\right)$ revealed by XRD. The small percentage of $\mathrm{K}_{2} \mathrm{O}$ and $\mathrm{Na}_{2} \mathrm{O}$ was reflected by the presence of a trace of K-feldspar and Na-feldspar which were detected by XRD. The presence of $\mathrm{MgO}$ content suggest that $\mathrm{MgO}$ is bonded in smectite and reflected the presence of dolomite $\left(\mathrm{CaMg}\left(\mathrm{CO}_{3}\right)_{2}\right)$. The loss on ignition indicated for the removal of hygroscopic water, loss of the interlayer water in the structure of clay minerals and calcite content.

\section{Chemo-physical analysis}

Cation exchange capacity (C.E.C): This test is usually applied to determine the capacity of clay to adsorb cations from solution. The cation exchange capacity is measured in terms of milliequivalent per 100 grams (meq/100 g). The Cation exchange capacity using methylene blue is specially designed to determine the montmorillonite ratio in clay samples.

- Preparation of 1 liter of nominally $0.01 \mathrm{M}$ methylene blue chloride solution by weighing out $3 \mathrm{~g}$ of methylene blue placed in 1-liter volumetric flask and add approximately $250 \mathrm{ml}$ of warm dis- tilled water (alternatively add $250 \mathrm{ml}$ of cold distilled water and warm using a water bath). Gently agitate flask until all the dye has dissolved and no solids remain on the floor of the flask. Allow to cool and add distilled water up to the 1-liter mark.

- Determination of CEC value [11]:

Weigh out $1 \mathrm{~g}$ of the sample and drying it at $105{ }^{\circ} \mathrm{C}$. Add $20 \mathrm{ml}$ of distilled water in a flask and disperse $0.2 \mathrm{~g}$ of the sample and agitating for 1-2 hours. Add $2 \mathrm{ml}$ of the nominally $0.01 \mathrm{M}$ methylene blue chloride solution from a $50 \mathrm{ml}$ burette and gently rotate the flask to mix the contents. After each $2 \mathrm{ml}$ addition, place a drop of the Suspension onto a filter paper using a glass stirring rod ("spotting"). Repeat until the end-point is reached. Spotting initially produces a distinct dark blue spot of clay absorbed dye surrounded by a clear halo of water. However, near the end-point spotting produces a dark blue spot of clay absorbed dye surrounded by a pale blue halo of excess dye. When this pale-blue halo is obtained leave to stand for 5 minutes and then repeat spot. If the pale-blue halo disappears add a further $2 \mathrm{ml}$ increment of dye. If after 5 minutes the pale blue halo persists, allow to stand for a further 20 minutes and repeat spot. If the pale blue halo then disappears cautiously add further dye. If the pale blue halo is still present after a period of 25 minutes, then the end-point has been reached. Record volume of methylene blue added at the end-point.

Calculate the methylene blue cation exchange capacity as shown by the following equation: 
Table 2: Cation exchange capacity of studied samples.

\begin{tabular}{|l|l|}
\hline Sample name & (C.E.C) $\mathbf{~ m e q} / \mathbf{1 0 0} \mathbf{g}$ \\
\hline Shale 1 & 60 \\
\hline Shale 2 & 45 \\
\hline Shale 3 & 35 \\
\hline Shale 4 & 70 \\
\hline
\end{tabular}
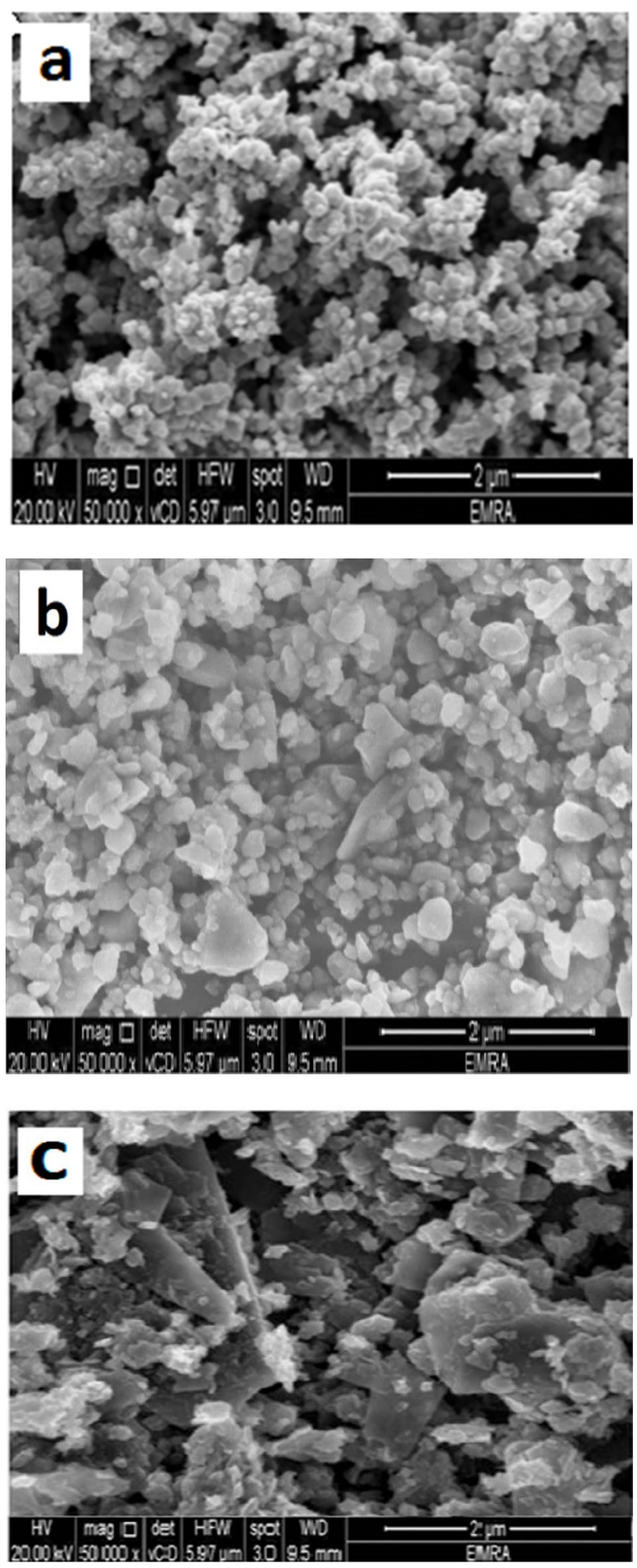

Figure 7: SEM of nanoparticles a) $\mathrm{CuO}$; b) $\mathrm{SiO}_{2}$ and c) Graphene nanoplatelets.
C.E.C (meq/100 g) $=(\mathrm{ml}$ of methylene blue $) /$ (weight of clay)

The Cation exchange capacity which reflect the montmorillonite content in the studied samples shown in Table 2.

\section{SEM of nanoparticles}

The morphology of nanoparticles samples was examined by scanning electron microscopy, $\mathrm{SiO}_{2}$ nanoparticles are semi-spherical like while Graphene shows platy like shape and $\mathrm{CuO}$ have spindly shape as shown in Figure 7.

\section{Shale Swelling Test}

\section{The effect of montmorillonite content in shale swelling}

Linear swell meter used to determine the swelling behavior of shale samples 1, 2, 3 and 4 with different montmorillonite content for $20 \mathrm{hrs}$. Drilling fluid based on 5\% OCMA bentonite used. From LSM data, we recognized that shale 1 swelled up to $75 \%$ of its initial length, while Shale 2 swelled up to $63 \%$, Shale 3 swelled up to $52 \%$ and shale 4 to $87 \%$ from its initial length. As shown in the Figure 8.

\section{Effect of potassium chloride $(\mathrm{KCl})$ on shale swell- ing}

Effects of $\mathrm{KCl}$ at a different concentration as additives to drilling fluids (OCMA, 5\%) on swelling of shales shows that the more montmorillonite content needs more concentration of $\mathrm{KCl} B y$ increasing the doses of $\mathrm{KCl}$ we found that, the effective dose for shale 1 was $7 \%$ and it decrease the swelling from $75 \%$ to $60 \%$ as shown in Figure 9. While shale 2 with dose $6 \%$ decreased from $63 \%$ to $49 \%$, Figure 10 , shale 3 with $4 \%$ decreased from $52 \%$ to $38 \%$ Figure 11 and Shale 4 which contain highest montmorillonite content needs dose $9 \%$ to decrease from $87 \%$ to $70 \%$ as shown in Figure 12 .

\section{Effect of nanoparticles on shale swelling}

Nanoparticles additive to drilling fluid using conventional process: Different doses of nanoparticles added to drilling fluid (OCMA 5\%) to inhibit swelling of shale. The doses used are $0.25 \%, 0.5 \%$, $1 \%$ and $2 \%$.

- Different doses of copper oxide (CuO) in nanoscale added to Shale 1 which swells without additives $75 \%$ give results $69 \%, 62 \%, 72 \%$ and $74 \%$ with $0.25 \%, 0.5 \%, 1 \%, 2 \%$ respectively. 


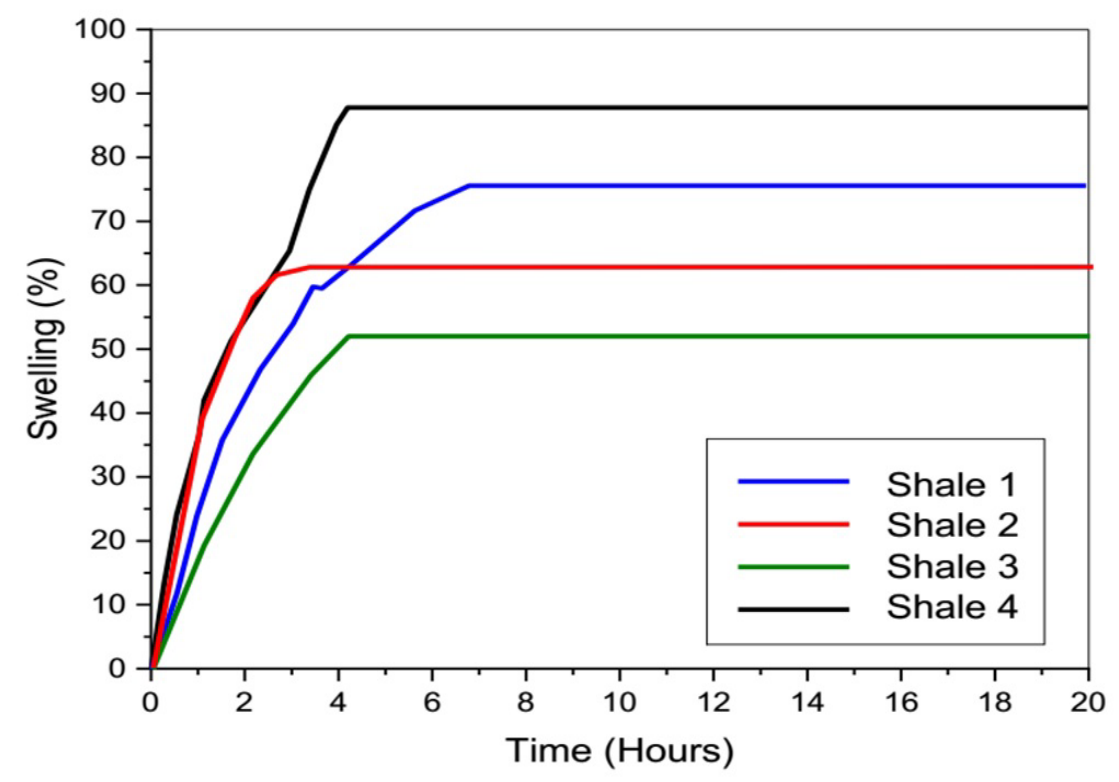

Figure 8: Showing the effect of OCMA bentonite with shale (1, 2, 3 and 4).

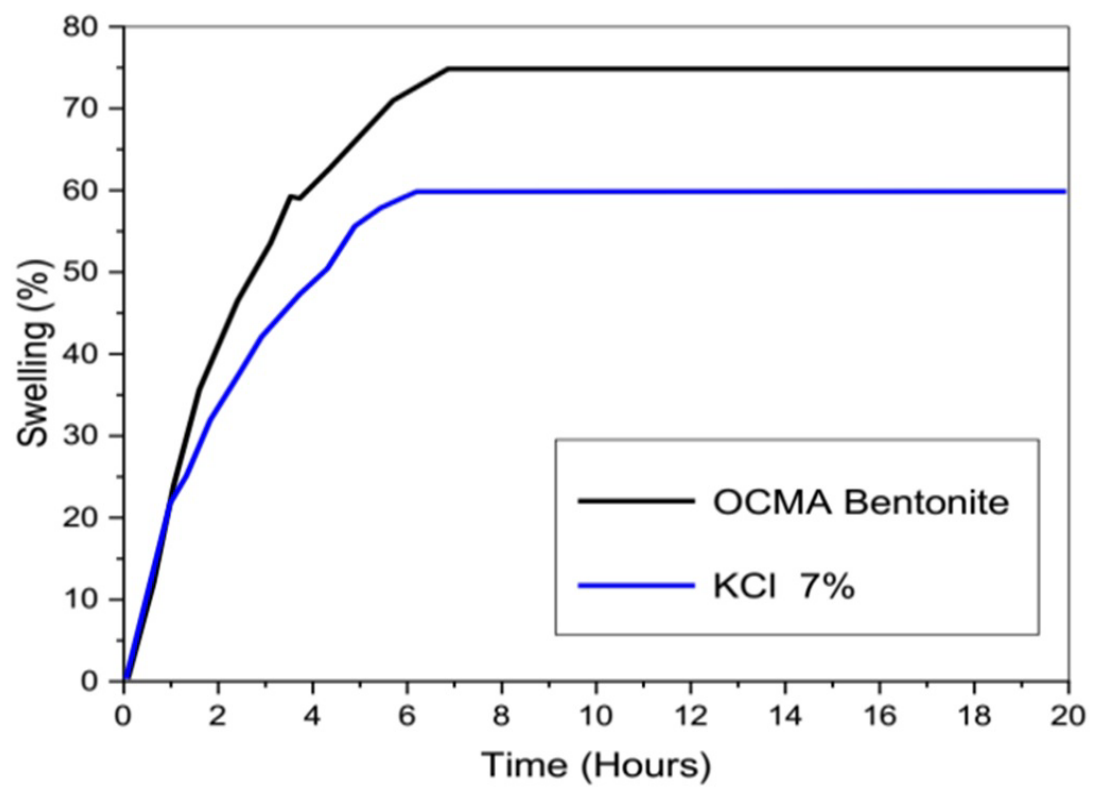

Figure 9: Showing the effect of $\mathrm{KCl}$ on shale 1.

While graphene. Nanoplatelets shows inhibition from $75 \%$ to $68 \%, 60 \%, 69 \%, 71 \%$ respective to $0.25 \%, 0.5 \%, 1 \%$ and $2 \%$. Silica nanoparticles $\left(\mathrm{SiO}_{2}\right)$ inhibited swelling from $75 \%$ down to $52 \%$, $62 \%, 68 \%$ and $70 \%$ with $0.25,0.5,1$ and $2 \%$.

- Shale 2 which swells to $63 \%$ inhibited by CuO nanoparticles down to $57 \%, 51 \%, 59 \%$ and $61 \%$ respective to $0.25 \%, 0.5 \%, 1 \%$ and $2 \%$, Graphene nanoplatelets showing inhibition 52\%, 48\%, $54 \%$ and $57 \%$ with $0.25 \%, 0.5 \%, 1 \%$ and $2 \%$ respectively. And $\mathrm{SiO}_{2}$ inhibited swelling down to $42 \%, 48 \%, 52 \%$ and $58 \%$ with $0.25 \%, 0.5 \%, 1 \%$ and $2 \%$ respectively.

- Shale 3 which swells to $52 \%$ inhibited by CuO nanoparticles down to $40 \%, 38 \%, 43 \%$ and $44 \%$ respective to $0.25 \%, 0.5 \%, 1 \%$ and $2 \%$, Graphene nanoplatelets shows inhibition $43 \%$, $40 \%, 47 \%$ and $48 \%$ with $0.25 \%, 0.5 \%, 1 \%$ and $2 \%$ respectively. While $\mathrm{SiO}_{2}$ inhibited swelling down to $30 \%, 34 \%, 36 \%$ and $42 \%$ with $0.25 \%, 0.5 \%, 1 \%$ and $2 \%$ respectively. 


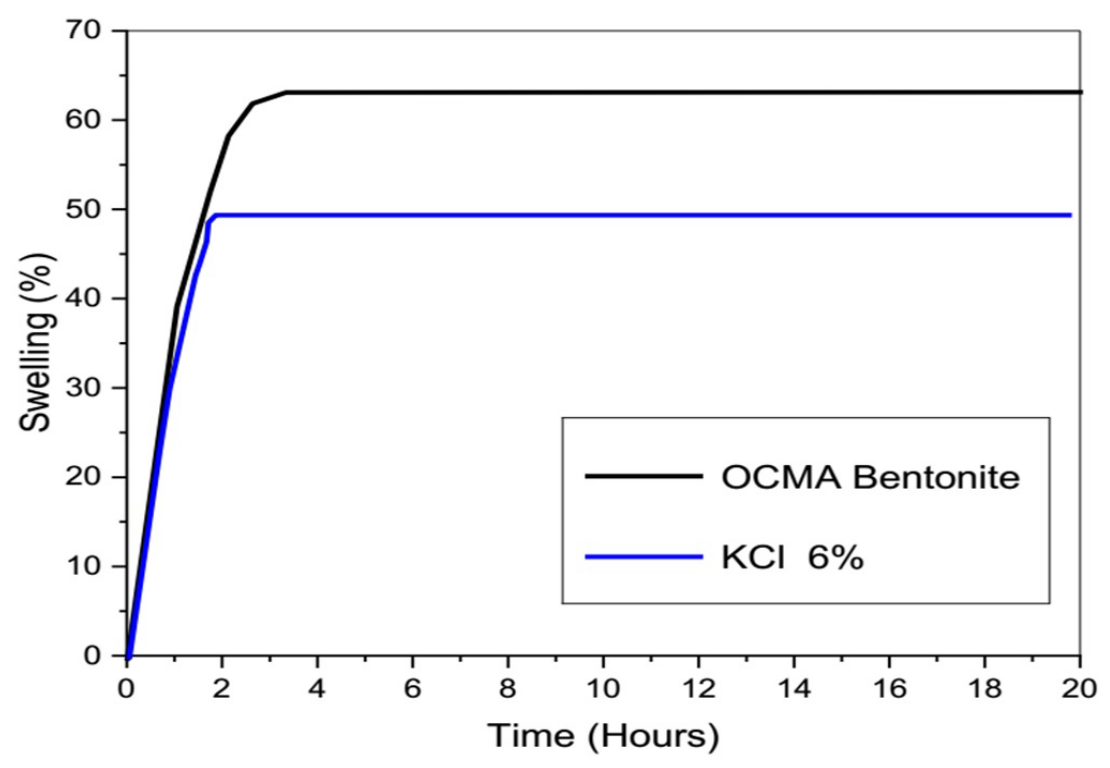

Figure 10: Showing the effect of $\mathrm{KCl}$ on shale 2 .

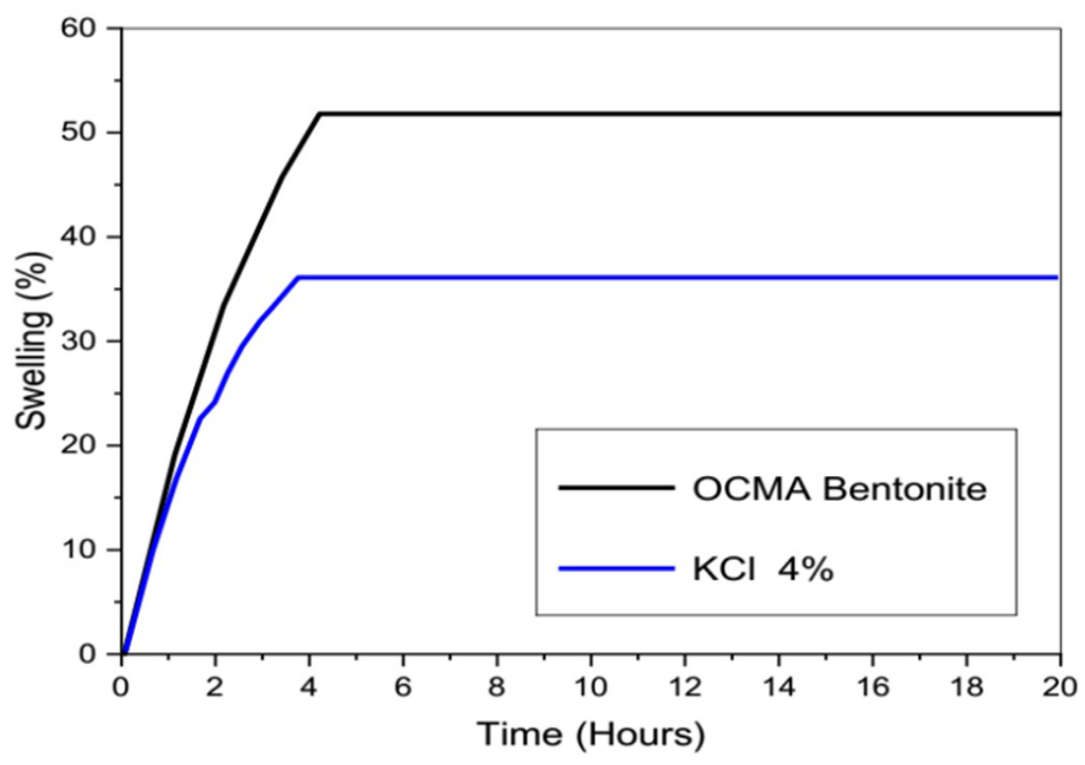

Figure 11: Showing the effect of $\mathrm{KCl}$ on shale 3.

- Shale 4 which swells to $87 \%$ inhibited by $\mathrm{CuO}$ nanoparticles down to $74 \%, 71 \%, 78 \%$ and $81 \%$ respective to $0.25 \%, 0.5 \%, 1 \%$ and $2 \%$, Graphene nanoplatelets shows inhibition $73 \%$, $69 \%, 77 \%$ and $81 \%$ with $0.25 \%, 0.5 \%, 1 \%$ and $2 \%$ respectively and $\mathrm{SiO}_{2}$ inhibited swelling down to $60 \%, 65 \%, 72 \%$ and $78 \%$ with $0.25 \%, 0.5 \%, 1 \%$ and $2 \%$ respectively.

Nanoparticles additive to drilling fluid using ultrasonic technique: Effect of nanoparticles $\mathrm{CuO}$, Graphene nanoplatelets and $\mathrm{SiO}_{2}$ as an inhibitor for shale swelling after using the ultrasonic technique.
In case of shale 1 , the utilization of $0.5 \%$ of $\mathrm{CuO}$ caused a decrease of swelling from $62 \%$ with conventional technique down to about $54 \%$ in case of ultrasonic technique, it's meaning that the ratio of inhibition about $21 \%$ as shown in Figure 13.

Addition of $0.5 \%$ of Graphene in case of shale 1 decreased swelling down to $60 \%$ with the conventional technique. However, $0.5 \%$ of Graphene after sonication caused a decrease in swelling down to $52 \%$, it is meaning that the ratio of inhibition about 23\% Figure 14. 


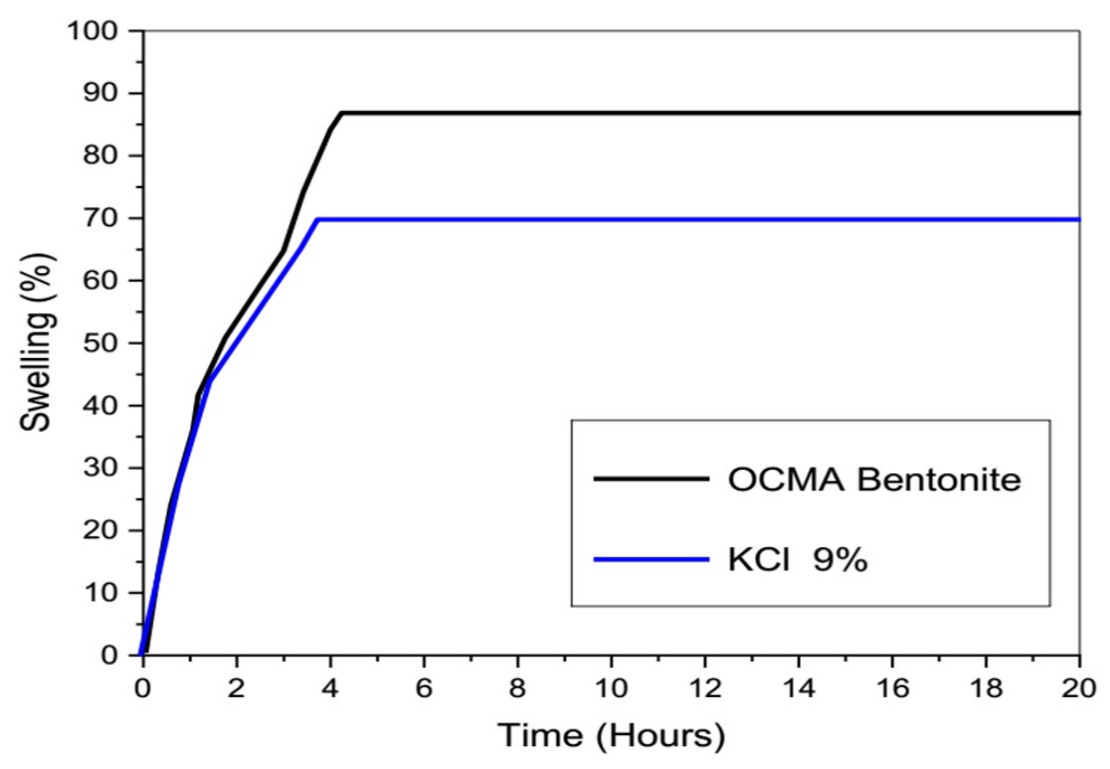

Figure 12: Showing the effect of $\mathrm{KCl}$ on shale 4.

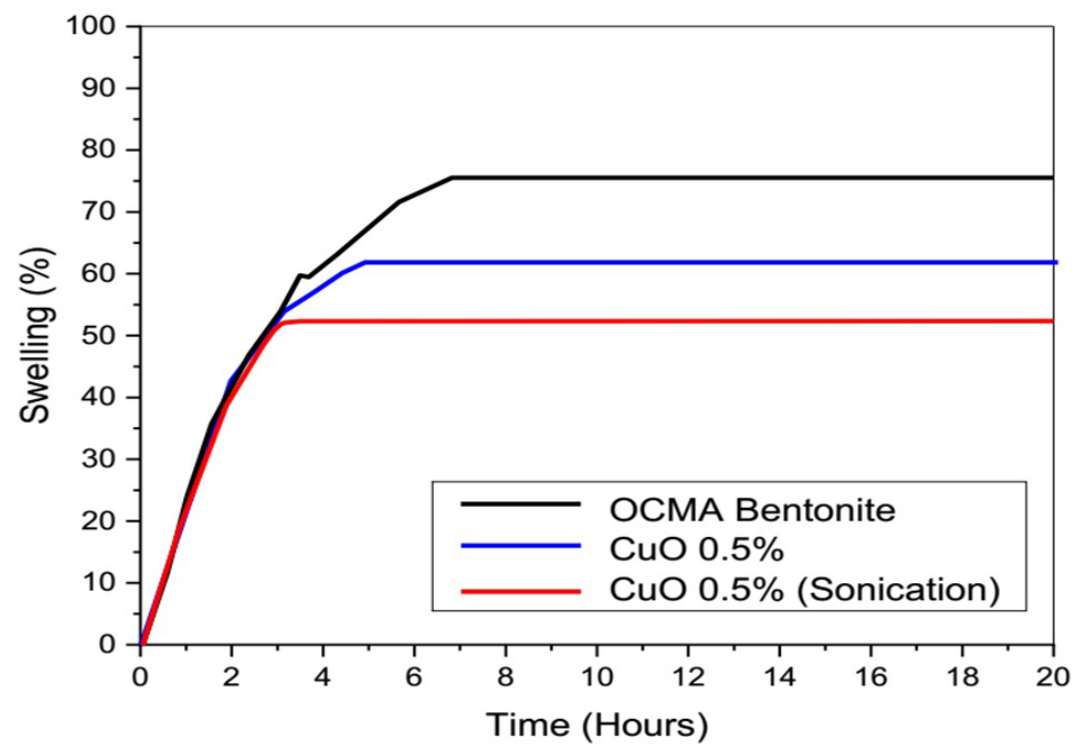

Figure 13: Showing the effect of $\mathrm{CuO}$ nanoparticles on Shale with and without sonication.

Inhibition swelling of shale 1 after applied $0.25 \%$ $\mathrm{SiO}_{2}$ using ultrasonic technique recorded the highest percentage compared with other nanoparticles using the same technique. It is recorded swelling about $41 \%$ Figure 15 compared to $58 \%$ in the case of conventional technique.

Shale 2 swelling with $\mathrm{CuO} 0.5 \%$ conventional technique inhibited from $63 \%$ to $51 \%$ while with ultrasonic decreased to 45\% Figure 16, Graphene $0.5 \%$ decreased it from $48 \%$ with conventional technique to $40 \%$ with ultrasonic Figure $17, \mathrm{SiO}_{2}$ $0.25 \%$ with sonication decreased it from $42 \%$ with conventional technique to $29 \%$ Figure 18.

Shale 3 swelling with $\mathrm{CuO} 0.5 \%$ conventional technique inhibited from $52 \%$ to $38 \%$ while with ultrasonic decreased to $30 \%$ Figure 19, Graphene $0.5 \%$ decreased it from $40 \%$ with conventional technique to $29 \%$ with ultrasonic Figure $20, \mathrm{SiO}_{2}$ $0.25 \%$ with sonication decreased from $30 \%$ with conventional technique to $21 \%$ Figure 21.

Shale 4 swelling with $\mathrm{CuO} 0.5 \%$ conventional technique inhibited from $87 \%$ to $71 \%$ while with ultrasonic decreased to 63\% Figure 22, Graphene 


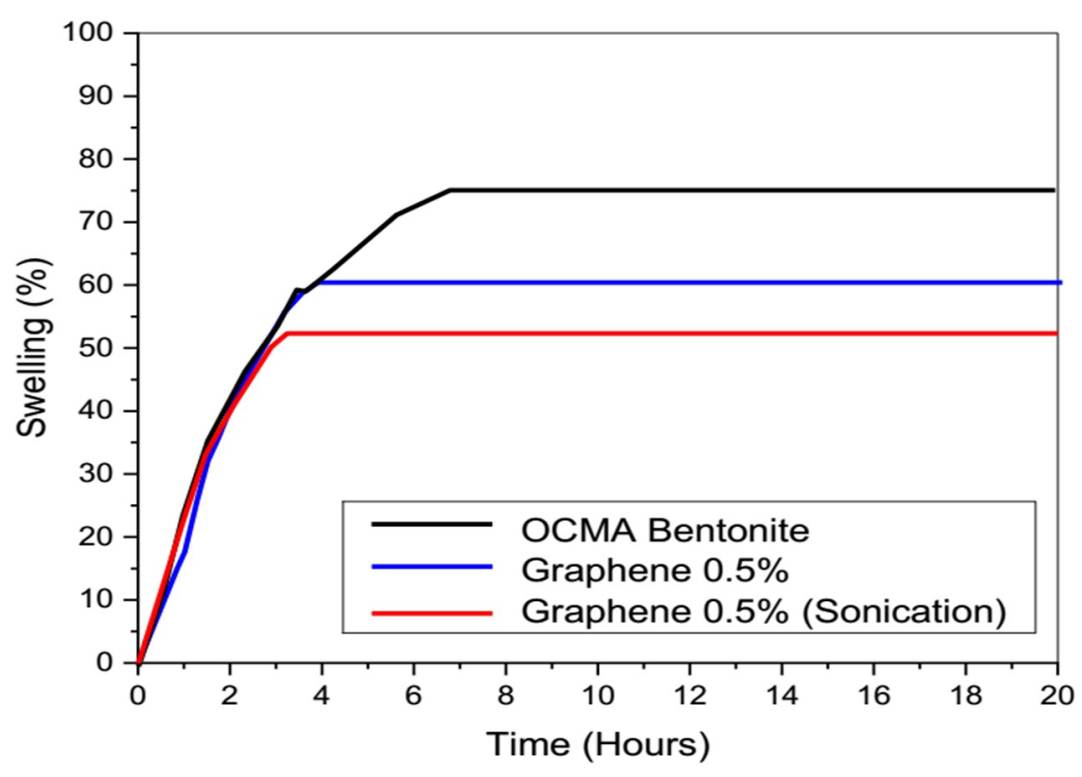

Figure 14: Showing the effect of graphene nanoplatelets on Shale with and without sonication.

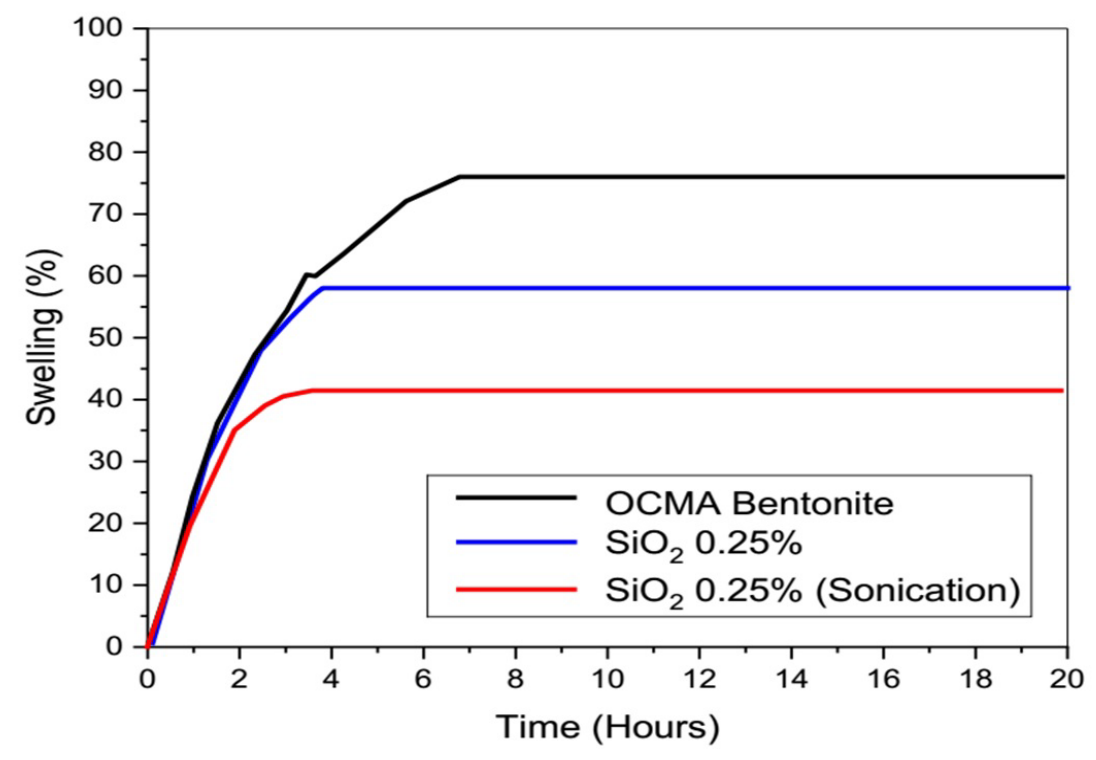

Figure 15: Showing the effect of $\mathrm{SiO}_{2}$ nanoparticles on Shale with and without sonication.

$0.5 \%$ decreased it from $69 \%$ with conventional technique to $57 \%$ with ultrasonic Figure $23, \mathrm{SiO}_{2}$ $0.25 \%$ with sonication decreased from $60 \%$ with conventional technique to 40\% Figure 24.

From previous data, we recognized that ultrasonic technique achieved more dispersion of nanoparticles into drilling fluid. The complete dispersion of nanoparticles permits these nanoparticles to plug nano-pore throat size of shale more than agglomerated particles in case of conventional technique [12].
Nanoparticles effective in reduction of clay swelling and it can be used as a permanent solution for the shale swelling problem because nanoparticles have potential to plug nano-pore throat size of shale and preventing water from flowing into the shale formation [4].

\section{Summary and Conclusions}

This study aims to minimize the shale swelling process throughout additive of potassium chloride $(\mathrm{KCl})$ and nanoparticles in water-based mud and using a linear swell meter and shale compact disks. 


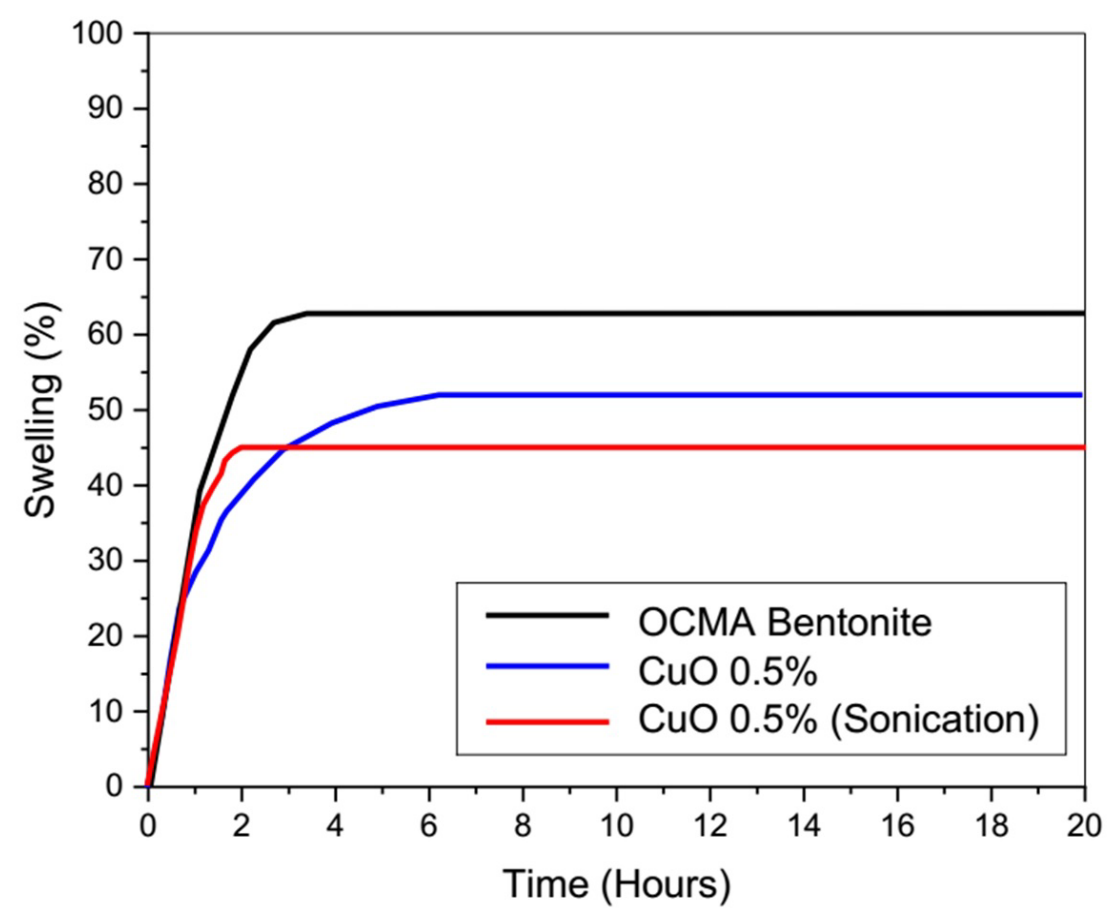

Figure 16: Showing the effect of CuO nanoparticles on Shale 2 with and without sonication.

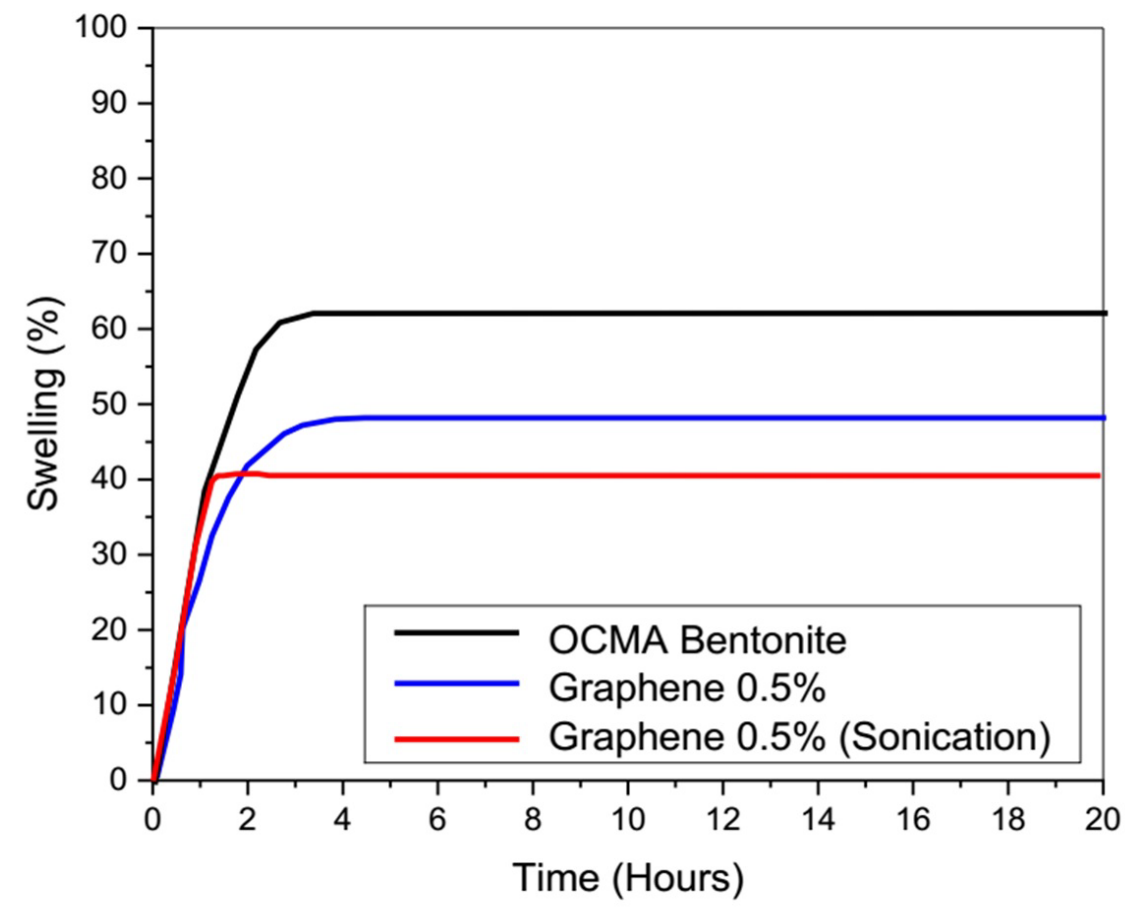

Figure 17: Showing the effect of graphene nanoplatelets on Shale 2 with and without sonication.

Shale samples grinded to $75 \mu \mathrm{m}$. The shale samples were analyzed using X-ray diffraction (XRD), $X$-ray fluorescence (XRF) and cation exchange capacity (CEC) using Methylene Blue (MB).

All the samples of drilling fluid are based on the formulation of $350 \mathrm{ml}$ of fresh water with $5 \%$ bentonite then mixed using a Hamilton Beach mixer for 15-20 min. Different percent of nanoparticles (CuO, Graphene nanoplatelets and $\mathrm{SiO}_{2}$ ) from $0.25 \%$ up to $2 \%$ and potassium chloride salt $(\mathrm{KCl})$ additive to bentonite with $350 \mathrm{ml}$ of fresh water and 


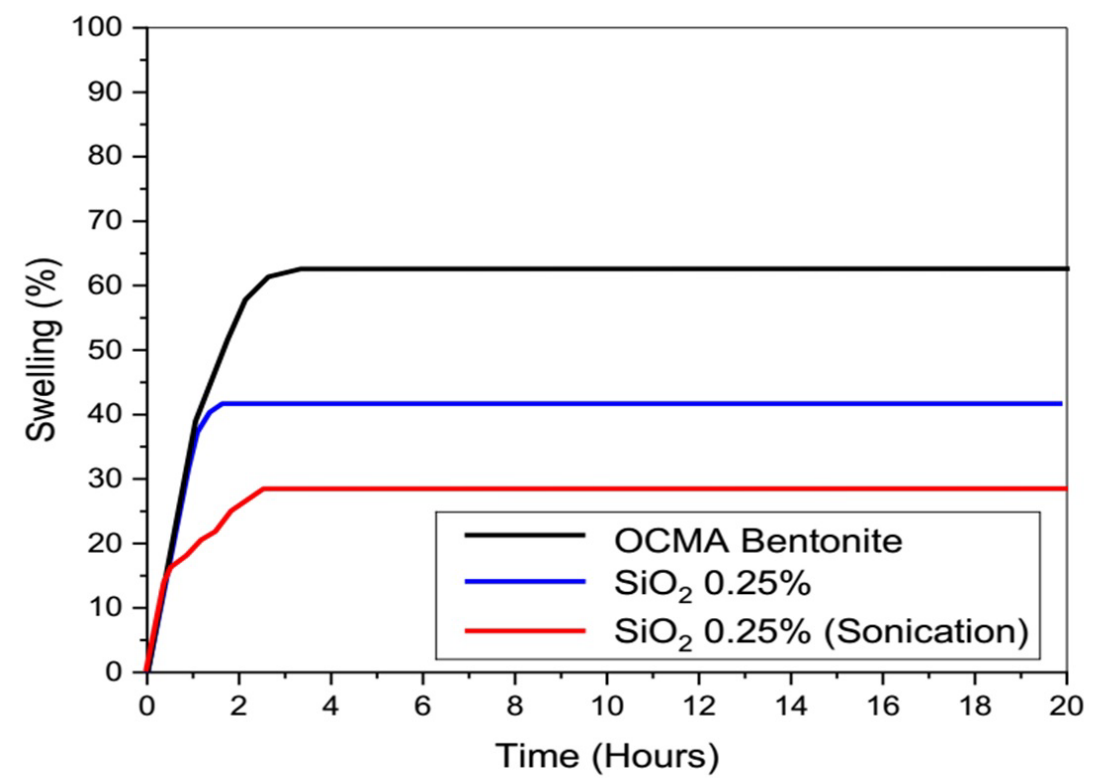

Figure 18: Showing the effect of $\mathrm{SiO}_{2}$ nanoparticles on Shale 2 with and without sonication.

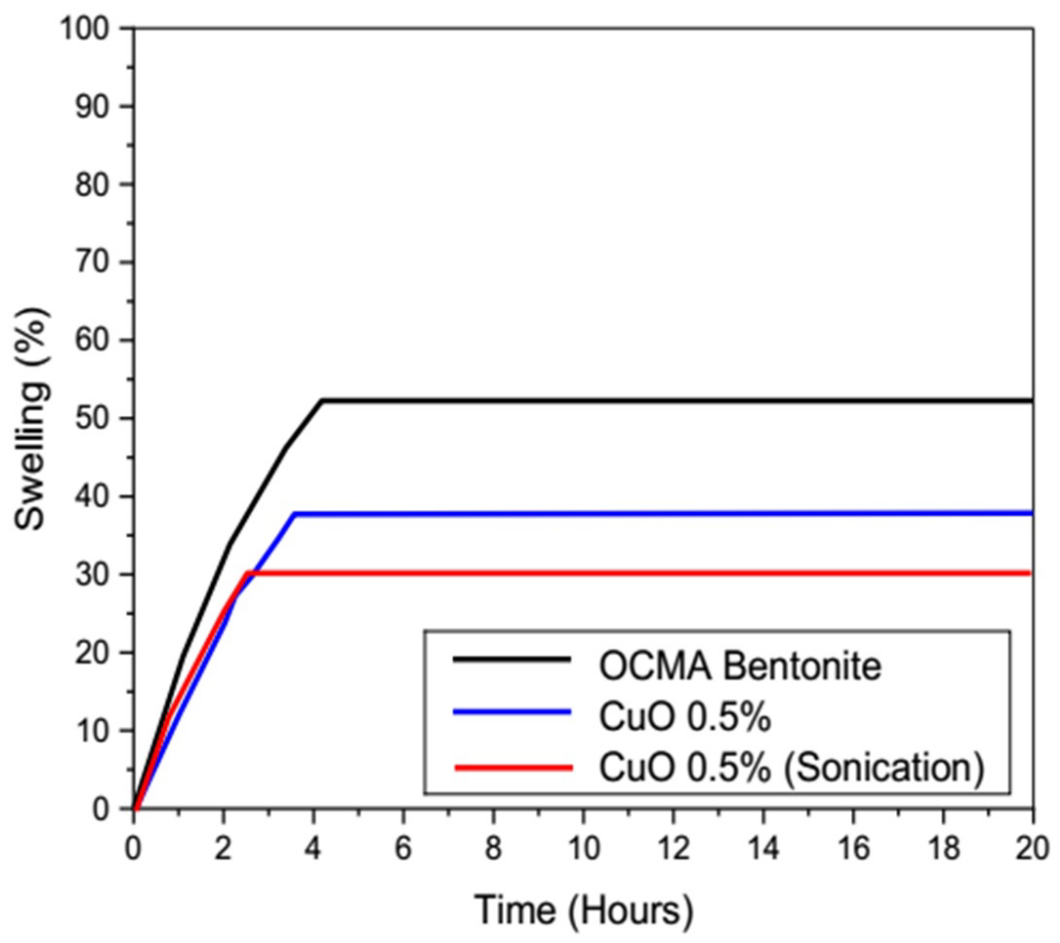

Figure 19: Showing the effect of $\mathrm{CuO}$ nanoparticles on Shale 3 with and without sonication.

studying effect these additives on shale swelling.

The following conclusions can be withdrawn from the previous results.

Swelling of shale directly related to montmorillonite content, more montmorillonite means more swelling in contact with OCMA bentonite.
Adding $\mathrm{KCl}$ to OCMA bentonite achieved decreasing in swelling but nanoparticles caused more decrease in swelling.

Nanoparticles were effective in the reduction of clay swelling and it can be used as a permanent solution for the clay swelling problem compared to $\mathrm{KCl}$. 
The mechanism of $\mathrm{KCl}$ and nanoparticles at inhibitor is different. Nanoparticles have potential to plug nano-pore throat size of shale and preventing water from flowing into the shale formation.
By comparing the results of the three nanoparticles, it was found that the $\mathrm{SiO}_{2}$ was more effective in minimizing the swelling percentage than $\mathrm{CuO}$ and Graphene nanoplatelets.

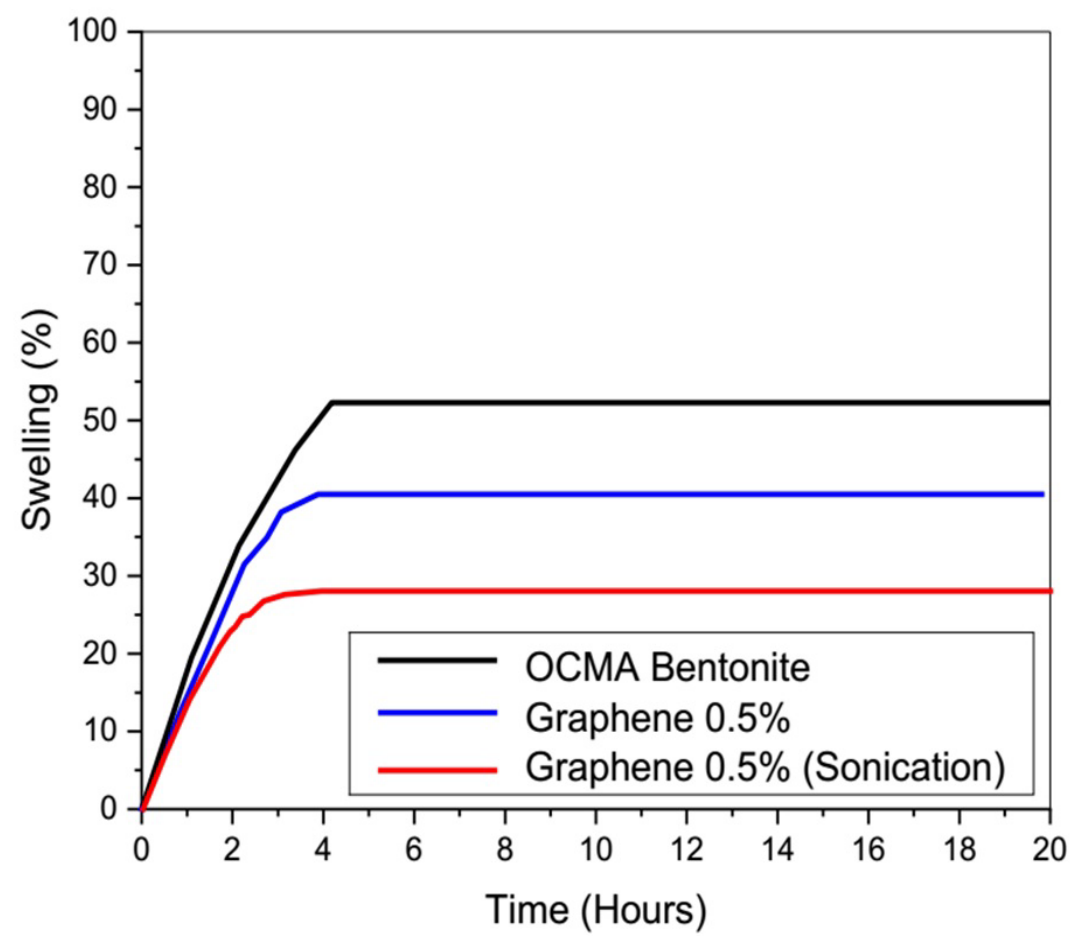

Figure 20: Showing the effect of Graphene nanoplatelets on Shale 3 with and without sonication.

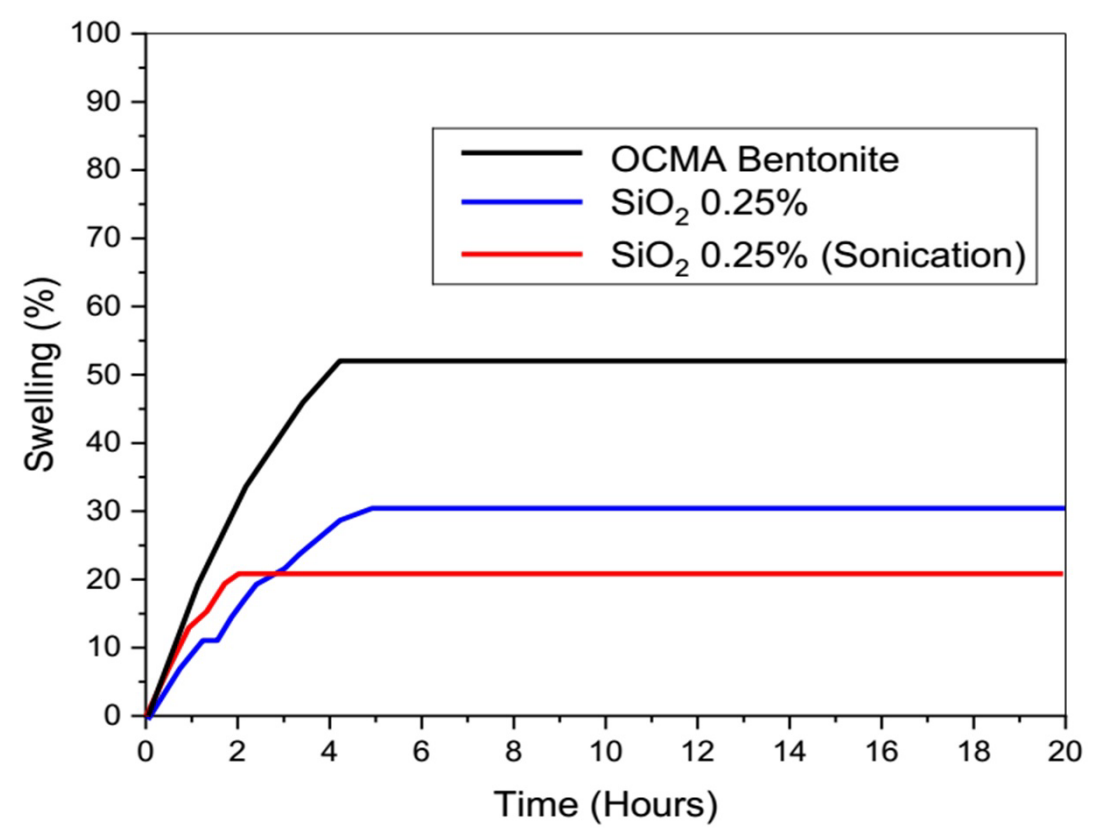

Figure 21: Showing the effect of $\mathrm{SiO}_{2}$ nanoparticles on Shale 3 with and without sonication. 


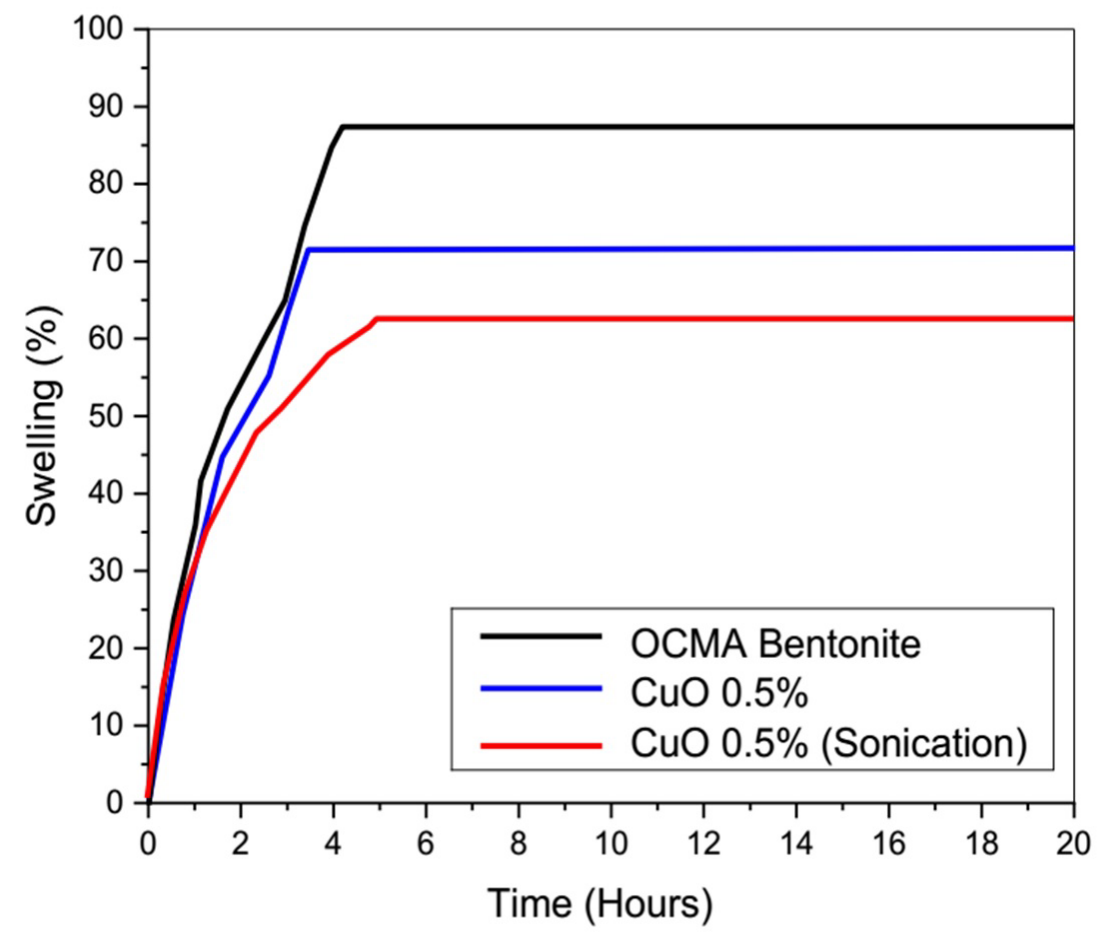

Figure 22: Showing the effect of $\mathrm{CuO}$ nanoparticles on Shale 4 with and without sonication.

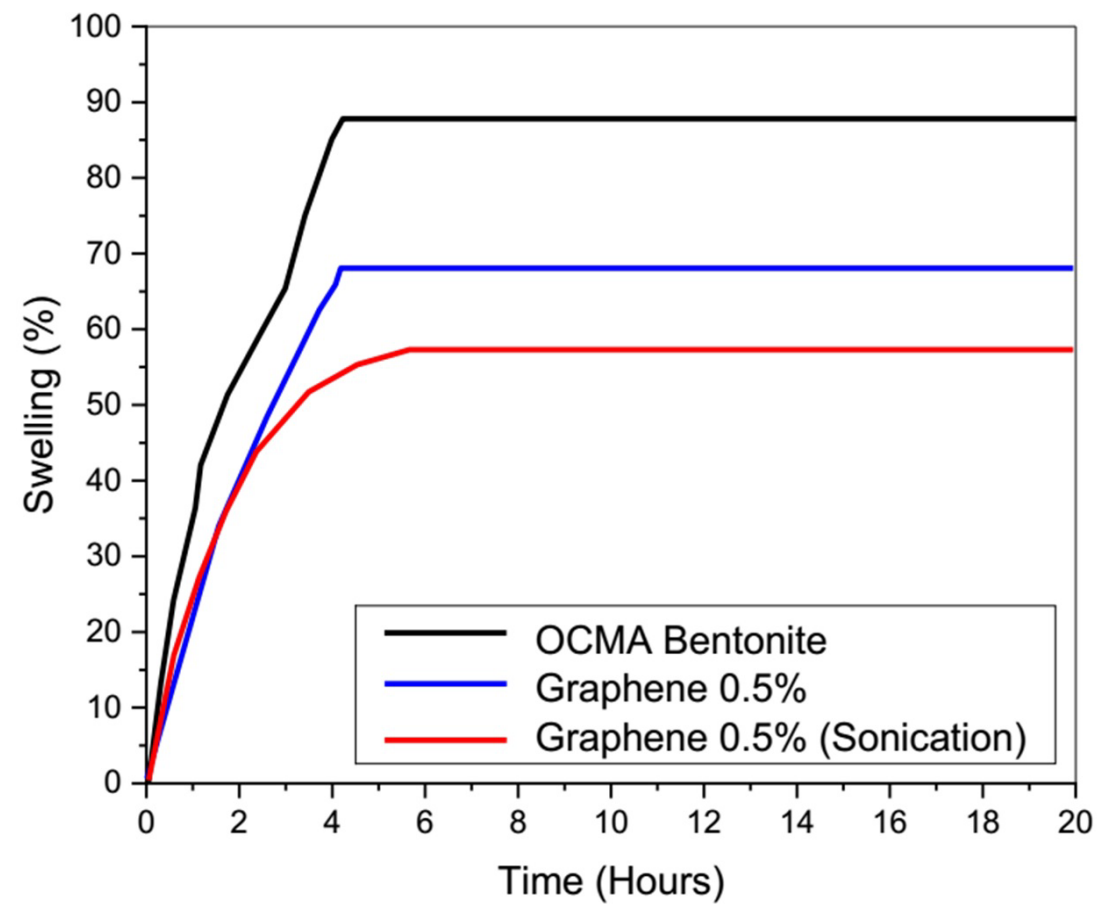

Figure 23: Showing the effect of graphene nanoplatelets on Shale 4 with and without sonication. 


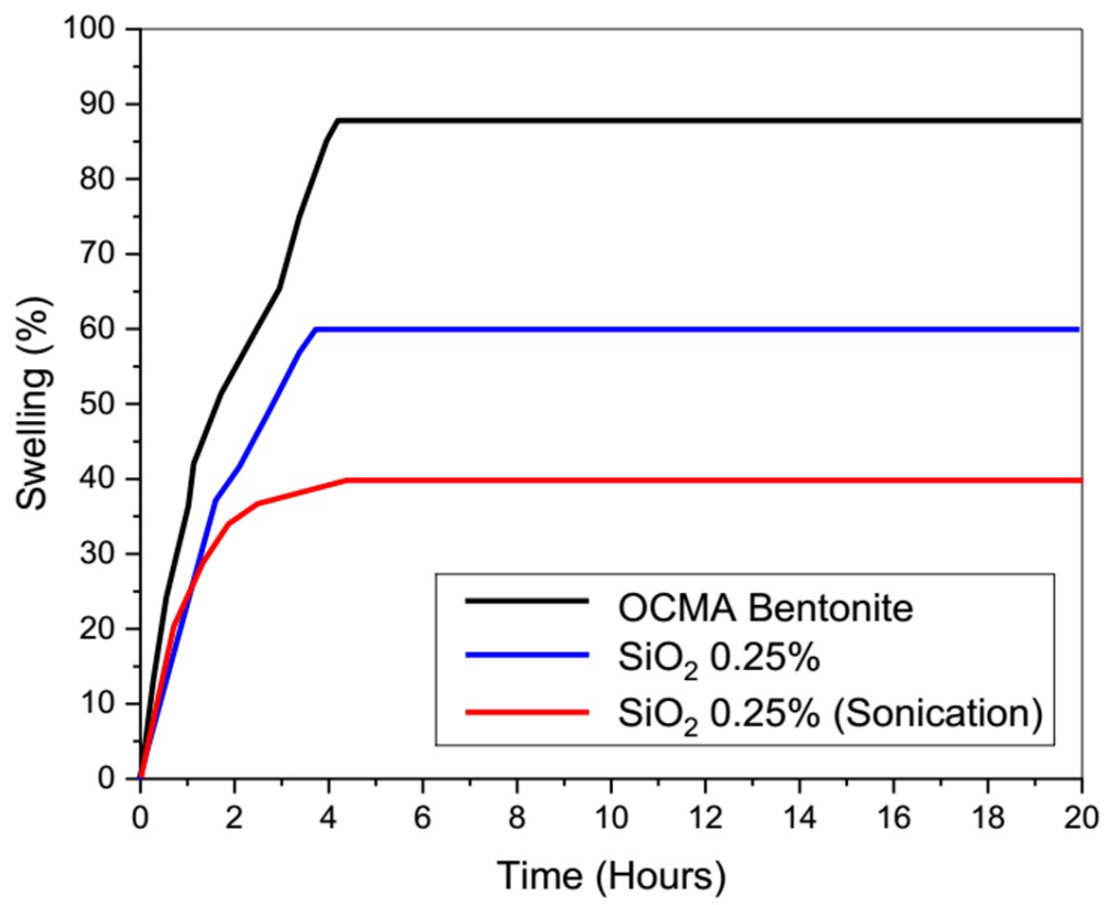

Figure 24: Showing the effect of $\mathrm{SiO}_{2}$ nanoparticles on Shale 4 with and without sonication.

\section{References}

1. Anderson RL, Ratcliffe I, Greenwell HC, Williams PA, Cliffe $S$, et al. (2010) Clay swelling - A challenge in the oilfield. Earth Sci Rev 98: 201-216.

2. Liu X, Lu X (2006) A thermodynamic understanding of clay-swelling inhibition by potassium ions. Angew Chem Int Ed Engl 45: 6300-6303.

3. O'Brien DE, Chenevert ME (1973) Stabilizing sensitive shales with inhibited potassium-based drilling fluids. Journal Petroleum Technology 25: 1089-1100.

4. Patel A, Goh C, Towler B, Rudolph V, Rufford TE (2016) Screening of nanoparticles to control clay swelling in coal bed methane wells. International Petroleum Technology Conference, Bangkok, Thailand.

5. Amanullah MD, Al-Tahini AM (2009) Nano-technology - Its significance in smart fluid development for oil and gas field application. Presented at the SPE Saudi Arabia Section Technical Symposium, AlKhobar, Saudi Arabia.

6. Baird JC, Walz JY (2006) The effects of added nanoparticles on aqueous kaolinite suspensions: I. Structural effects. Journal of Colloid and Interface Science 297: 161-169.

7. Sensoy T, Chenevert ME, Sharma MM (2009) Minimizing water invasion in shales using nanoparticles. Presented at the SPE Annual Technical Conference and Exhibition, New Orleans, Louisiana, USA.
8. Abrams A (1977) Mud design to minimize rock impairment due to particle invasion. Journal of Petroleum Technology 29: 586-592.

9. Hassan MS, Salem SM (2001) Distribution and influence of iron phases on the physico-chemical properties of phyllosilicates. Chinese Journal of Geochemistry 20: 120-129.

10. Moore DM, Renyolds RC Jr (1979) X-Ray Diffraction and the Identification of Clay minerals. Oxford University Press, Oxford.

11.Inglethorpe SDJ, Morgan DJ, Highley DE, Bloodworth AJ (1993) Industrial minerals laboratory manual bentonite. Technical Report WG/93/20, Mineralogy and Petrology Series. British Geologic Survey, UK.

12. Mahbubul IM, Chong TH, Khaleduzzaman SS, Shahrul IM, Saidur R, et al. (2014) Effect of ultrasonication duration on colloidal structure and viscosity of alumina-water nanofluid. Ind Eng Chem Res 53: 6677-6684. 